\title{
The Design of Plant Fibres as Biomimetic Composites
}

Carlo Santulli ${ }^{(1)}$

\begin{abstract}
Plant fibres, which are based on lignocellulosic structures, are arranged as biomimetic composites, in the sense that they include a complex relationship between a softer matrix and a harder reinforcement through an interface, with continuous use of porosities and cellular arrangements. However, the fibres can be extracted from different parts of the plant according to the species, in practice from the stem, the bark, the fruit, the leaf or even the seed. There is a relation between the fibre region and their structure, which this work aims to discuss, presenting a large variety of fibres, geometries and collocation in the plant itself.
\end{abstract}

Keywords: Plant fibres - Lumens - Kink bands - Loading support - Natural design

[Abstracts in spanish and portuguese at page 143]

(1) Carlo Santulli. Laurea in chemical engineering (Roma-La Sapienza, 1991), PhD in materials science and technology (University of Liverpool, 2000), MSc in environmental decision making (Open University, 2004), laurea in arts (Roma-La Sapienza, 2001) is an associate professor in Università degli Studi di Camerino since 2012. He lectures on waste management, materials science and environmental sustainability. His research interests are on composite materials, natural fibres and sustainable materials, waste management and upcycling, and biomimetics. He has around 30 years of experience in this field, working in Università di Roma - La Sapienza (1991-93 and 2006-2010), JRC Ispra (1994-1998), University of Nottingham (1999-2001), University of Reading (2001-2006) and Seconda Università di Napoli (2010-2012). He has been invited researcher and professor at Katholieke Universiteit Leuven, Ecole des Mines de Saint Etienne, Université de Rouen, Università di Bologna, Universiti Teknologi Malaysia, Universiti Putra Malaysia and Bangalore University. He has published 197 journal papers, 22 book chapters, and 93 conference papers, with $\mathrm{H}$-index 40 and i-10 index 108. He also acts in dissemination of environmental and sustainability themes in schools and other contexts in Italy. carlo. santulli@unicam.it 


\section{Introduction}

Multifunctional surface structures of plants have often served as inspiration to biomimetics design, in terms of suggesting how to improve the relation with fluids, such as air, water and oil of the engineered materials (Koch et al., 2009, pp.137-178). In practice though, the real use of natural materials, such as fibres extracted from plants has always been based on a "replacement" concept against other synthetic material, a concept that becomes more stringent nowadays dealing with sustainability. In other words, it might not be sufficient to use synthesized materials according to what they can suggest in terms of bio-inspiration, such as it has been the case e.g., for Velcro or phone covers inspired to gecko. In contrast, it would be also important to use biological materials according to their inherent potential, which make them suitable to being applied in natural structures, such as plants. In the last decades, also on the suggestions made by Michael Ashby and his co-workers, natural materials have been considered alongside engineered ones (Wegst \& Ashby, 2004, pp. 2167-2186). This implies a number of consequences: first of all, their physical (mechanical, thermal, optical, acoustical, etc.) properties have been compared regardless of the material origin, whether it comes from nature or it has been developed at a certain time during human history and continuously improved over time. Nature, after Darwin, is recognised to have the capability to evolve too, gradually leading to species that are more able to survive and effective in operating in their specific environment of life (Gu et al., 2015, pp. 464-478).

This gradually enhanced ability to design of nature, achieved of course over the whole geological history of our planet and therefore that, in the case of materials, can be revealed only by some scant observations, for example in the case of mineralized structures (Luz \& Mano, 2010, pp. 1777-1788). This includes also the creation of structures able to withstand stresses applied during life in plants and animals. These structures are produced using a hierarchical approach (bottom-up) starting from the cell and employing a very limited number of materials. In particular, in nature metals are rarely present as such, only being available when chemically bound in oxides, carbonates, or silicates, etc., which form most part of the minerals that constitute the solid part of the geosphere. As the consequence, materials to form structures in nature are limited to polymers and ceramics. More specifically, the former can be divided in two large categories, polysaccharidic and proteinic ones, the respective monomers being sugars and amino-acids.

Concentrating on plants, the structures that have been used in human history have been normally based on the availability of a sufficiently long stretch of ligno-cellulosic material, therefore constituted principally by an organised polysaccharide, referred to as "cellulose". There is also a filler in the space between the cell membranes of ligneous plants in very variable thicknesses and forms, depending on the species, define as "lignin". This is constituted by a mixture of alcohols, namely coniferyl, p-coumaryl, and sinapyl (Patil et al., 2016, pp. 27-47). A first distinction can be based on the fact that cellulose is capable to absorb significant amounts of water, while lignin is typically hydrophobic. Other less ordered polysaccharides, defined collectively as "hemicelluloses", can also be present, together with natural glues, such as pectins, waxes, etc. 
The sufficiently long stretch of material extracted from the plant, which are able to provide a sufficient tensile strength, normally for textile or roping use, are therefore referred to as "technical fibres". It is normally accepted that these used started well before than the plants were cropped for other uses, therefore exploiting the wide availability of some spontaneous plants, such as nettle (Haugan \& Holst, 2014, pp. 951-960). In these applications, the evidence of the hierarchical structure is only revealed by the fact that from the technical fibres normally wires, yarns or strands are obtained, using a torsion force to keep the fibres together also through a friction force. More recently the effect of torque angle, which depends, as microfibrillar angle, from the hierarchical structure itself, together with the surface topography of the fibres, has also been elucidated (Mizuno et al., 2013, pp. 5857-5862). In contrast, the occurrence of fibrillation, hence separation of the single fibres may also occur. This again depends on the hierarchical structure, which is perceived more as a problem than as an opportunity: in fact, attempts to modify the surface topography to reduce proneness to fibrillation by linking other polysaccharides to the fibres have also been proposed (Doineau et al., 2020).

\section{The engineering use of Plants Fibres}

More recently, plant fibres have obtained an interest, directly derived from their textile application, as the replacement for glass fibres and in hybridisation also with other fibres, such as carbon and basalt, in composite materials. A large number of studies do exist in this sense: two recent reviews are offered by Nguong et al., 2013, pp. 52-59 and Peças et al., 2018. However, this application does not usually account for the different characteristics of plant fibres with respect to engineered ones, such as their hydrophilicity, the presence of lumen or lacunae in their section and ultimately their hierarchical structure, which has been hardly ever seen as an opportunity for these plant fibre composites (Santulli, 2008, pp. 95-114). This comes from the cultural limitation of seeing plant fibres as a "replacement" for synthetic fibres rather than as an autonomous material in its fullest sense, which therefore does not have to adequate to our engineering purposes, based especially on compact structures built with a straight line and constant thickness philosophy

What is discussed above reports only the cases in which the macrostructure of plant fibres has been left unaltered, apart from treatment (chemical, physical or enzymatic) that modifies the section geometry of the fibre (Kalia \& al., 2009, pp. 1253-1272). This does not occur though not in a selective, but rather in an undifferentiated way, trying to lead to a shape closer to the cylindrical one to provide a better adhesion to the polymer matrix in the case of composites. Rather the idea should be for the treatment to be targeted, therefore designed to improve surface hydrophilicity, while also increasing moisture tolerance and microbiological resistance (Liu et al., 2017, pp. 660-683). A further step is recognising that plant fibres are in themselves natural composites for the combined presence of cellulose and lignin and that there is a relation between their microstructure and their properties, though not of immediate comprehension. This would need to account for the species differences, which has become of paramount importance in the last decades, consider- 
ing that over a few dozens of species, even not considering the various cultivars of each, have been proposed and used as the reinforcement in polymer composites (Ahmad et al., 2015). The considerations developed in the following sections are aimed at making sense of the experience accumulated in terms of the characteristics features of plant fibres for their engineering applications, especially in polymer composites. This information would allow investigating the elements that constitute the relation between natural structure and properties while also offering indications for its further study.

\section{The external design of Plant Fibres}

The interest for the internal structure of plant fibres has been raised in materials engineering by the need to measure some mechanical parameters, which are essential for the comprehension of the material and therefore its further use. These are in particular, in the case of fibres, for example the aspect ratio (length/diameter), also defined as "slenderness ratio", especially in paper fabrication, and the tensile stress. Both of these parameters require the measurement of the equivalent diameter and also the internal percent of void in the fibres, due to the presence of lumens and lacunae. This has been done in the first case by the calculation of correction factors with respect to a circular diameter, therefore obtaining an equivalent diameter distribution over a fibre batch, such as that which can be used as the reinforcement of a composite (Summerscales et al., 2011, pp. 5876-5880). As far as the presence of internal voids is concerned, a back calculation of Young's modulus from nanoindentation results to correct macroscopic values from tensile testing has been found reasonable and applicable (Bourmaud et al., 2019). Tensile loading proved effective as a way to highlight the prevalent mechanisms leading to fracture, which are juxtaposed and follow each other during testing. These are in particular the development during loading of low diameter stretches, kink bands, branching and void-generated flaws, which are alternative modes in which damage can progress (Yue et al., 2019), which are schematised in Figure 1. It is suggested that these are all ways in which nature produces a damage-tolerant structure.

Beyond mechanical calculations and micro-modelling, further considerations would concern the different geometries of the fibre sections, which depend in the first place on the respective amounts of cellulose and lignin, and also on which part of the plant (stem, leaf, fruit hair, seed hair) the fibres originate. In Table 1 a number of examples of fibres on which there are examples of use in textile, in composites or others, such as for the obtention of active carbons (Wang et al., 2020) are reported in literature. (The list is not exhaustive, some more indications and suggestions are available in Sarasini \& Fiore, 2018, pp. 240-267). 


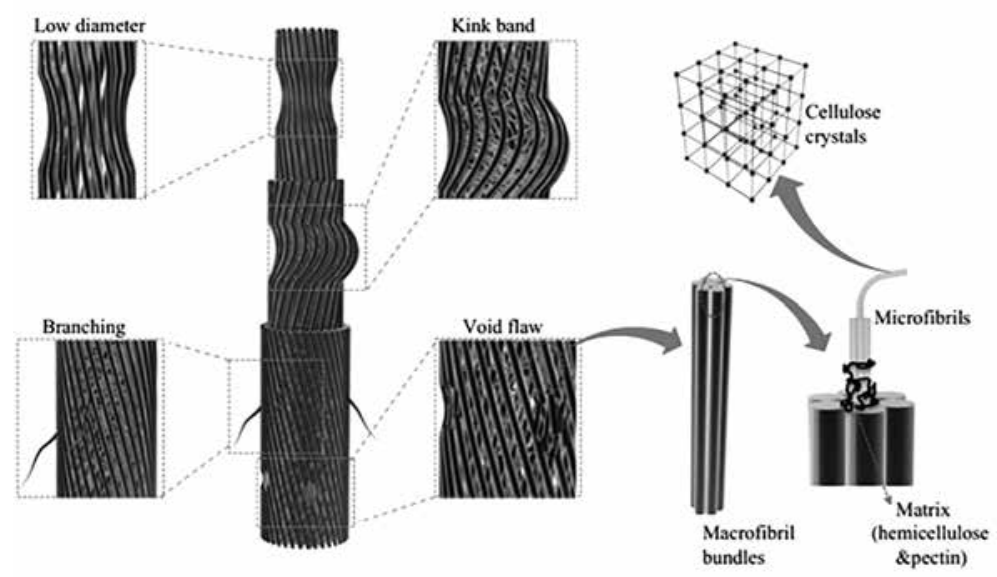

Figure 1. The different ways of supporting loading from a plant fibre (Yue et al., 2019).

\begin{tabular}{|l|l|}
\hline Origin & Examples of fibres \\
\hline $\begin{array}{l}\text { Bast (stem) (also herbaceous stem or agave } \\
\text { cladodes) }\end{array}$ & $\begin{array}{l}\text { Abaca, bamboo, esparto, flax, giant reed, hemp, } \\
\text { Indian fig, jute, kenaf, nettle, okra, ramie, } \\
\text { roselle, sisal, Spanish broom, sunn hemp }\end{array}$ \\
\hline Leaf & $\begin{array}{l}\text { Banana, date palm, phormium, pineapple, } \\
\text { sansevieria }\end{array}$ \\
\hline Fruit hair & Coconut, oil palm, plane tree \\
\hline Seed hair & Cotton, kapok, Metaplexis japonica, poplar \\
\hline
\end{tabular}

Table 1. Types of fibres that have some interest for textiles and composites.

Kink bands, which are a commonly observed feature, and are increasingly noticeable during loading, are the effect of the not total crystallinity of the plant fibre structure, so that only some regions are ordered, which results in local weakness of the fibres (Melelli et al., 2021). On the other side, total crystallinity would in practice result in polymer composites, such as plant fibres, having a very limited deformation under applied stress, despite them being normally composed on a mixture of I $\alpha$ and I $\beta$ cellulose (Sfiligoj Smole et al., 2013, pp. 369-398). The degree of polymerisation of the microfibrils of cellulose may be very different, from around 20 chains into herbaceous stems up to even 80 chains in stems with a considerable secondary cell wall development, such as flax, which offers a higher yield in the production of crystalline nanocellulose (Jarvis, 2018). 
Optimizing plant cell walls structures appears also of paramount importance to improve the properties of plant fibres, also for their use in engineered polymer composites. In particular, morphological and mechanical characteristics of the cells are not only linked to the specific plant and the part of it from which they come from, but also depend on their biochemical composition, starting with their lignin/cellulose ratio, and plant growing conditions (Bourmaud et al., 2018, pp. 347-408). In practice, it has been described that modifying the decortication process, for example on flax fibres, may reduce the occurrence of kink bands in the material (Zheng et al., 2015, pp. 1-7). However, it is notable that kink bands are related to the need for the material to undergo local plastic deformation in order to be able to reduce the occurrence of brittle fracture, not very differently from what occurs in metals with dislocations. In practice, in plant fibres, these defects are named in three most common ways: kink bands, dislocation and nodes, which all indicate localised distortions of the cell walls (Ahmed \& Ulven, 2018). Conversely, the different names emphasize the size of the effect obtained: dislocations tend to be a molecular phenomenon, kink bands appreciate the shear sliding effect in the ultrastructure, and nodes are typically a macroscopic imperfection of the plant itself. In particular, nodes are seen as possible hindrances in the extraction and use of fibres in some specific uses, for example in paper production normally internode stretches are only employed, such as it is the case for plants such as kenaf (Hibiscus Cannabinus) (Ververis et al., 2004, pp. 245-254) or giant reed (Arundo donax) (Chen et al., 2019, pp. 192-199).

\section{The internal design of Plan Fibres}

Sectioned views of plant fibres offer a number of information on their geometry and on the distribution of the void spaces in it, other than possibly on the different hardness of various parts of it. Cellular spaces are also distributed with different levels of contact and coalescence between them, bordering into each other, in the form of lumens or lacunae.

A distinction needs to be done between the different cellulosic tissue that possibly constitute fibres. In particular, textile ones, such as the fibres from flax and hemp and the most commonly used ones are formed by secondary wall sclerenchyma, while others, softer and able to be used as such normally in the form of short fibres, are collenchyma primary wall cells, such as those e.g., from celery (Šturcová et al., 2004, pp. 1333-1339). It is noticeable as the latter one does not provide a real lumen, but rather can be exploited for a distributed porosity, which appears a significant characteristic in acoustical rather than in mechanical terms, as it can be observed in Figure 2. In practice, fibres with these characteristics, which may also present some secondary thickening of cell walls, can be suggested for use in the case when enhanced tortuosity is desired, which makes the sound path more difficult. This is the case for example for Yucca gloriosa (Soltani et al., 2020), as it is depicted in Figure 3, or also for luffa, which has been found some applications even in fibrous form in composites (Koruk \& Genc, 2015). 


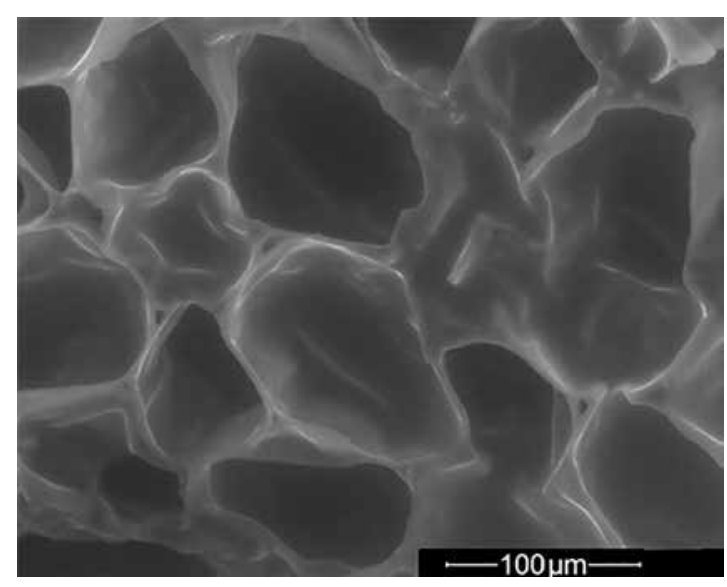

2
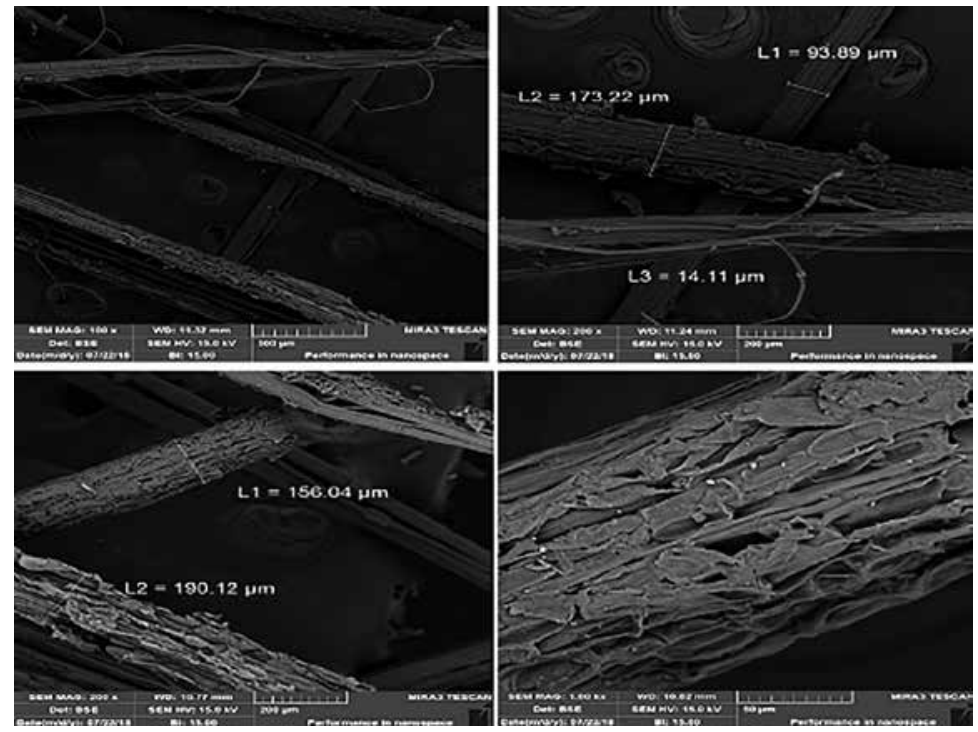

3

Figure 2. Cell structure of celery fibres. Figure 3. The structure of possible acoustic insulation foam obtained from Yucca gloriosa fibres (Soltani et al., 2020). 
As concerns the geometry of fibre section, a number of general shapes can be elicited: some fibres retain the quasi-circular shape, such as it is typical for banana fibres, although a diameter variation of more than $50 \%$ over its length (Mukhopadhyay et al., 2008). An initial deviation from circularity is the occurrence of polygonal fibres e.g., observed by De Rosa et al., 2011, pp. 246-254, on okra. The most diffuse section geometry however is being oval with very variable eccentricity, such as it is typical in the case of most bast fibres, such as in the case of flax, hemp, jute, or abaca, shown in Figure 4. In the last case also a dependence of the geometry of the observed fragment on its height on the fibre stem (Liu et al., 2013, pp. 14-22). Other possible geometries are considerably more removed from the circularity and indicate the need of the fibre to adapt to the larger structure of which it participates. These are characteristic of leaf extracted fibres, such as for example horseshoe or keyhole, well investigated in New Zealand flax (Phormium tenax) (Newman et al., 2010, pp. 353-359). Other complexities arise in fibres such as cotton, a seed hair fibre with arched shape declined in countless ways: this is interesting, because cotton has been modified intensely through mercerization to make it adaptable to textile uses. Two cases of forms taken by cotton fibres with the typical slit-like lumen yet with different levels of maturity and geometries, are reported in Figure 5.

This irregularity has also been explored through mathematical coefficients, in particular in the case of flax, one of the most explored fibres (Mattrand et al., 2014, pp. 10-20). The parameters explored are the Feret width and the Feret ratio (Walton, 1948, pp.329-330), the geodesic circularity (Legland \& Beaugrand, 2013, pp. 253-261), as related to the distribution of their relative dimensions, the tortuosity by considering them as foamed materials (Carniglia, 1986, pp. 401-418), and the convexity.

Convexity has another possible meaning in expressive terms, because some cellular structures of natural fibres, though resembling in section to a honeycomb, may present some cell concavities, which might suggest their behaviour as auxetic materials, which have negative Poisson's ratio, therefore inflect over the three dimensions, instead of thinning when stretched (Santulli \& Langella, 2016, pp. 20-37). The use of natural fibres, though mainly protein- and not cellulose-based, to produce auxetic materials, have as a matter of fact been investigated already e.g., by Verma et al., 2020. This could be explored further and at a microscopic level by investigating the buckling behaviour of these fibres, hence compressing them with a low slenderness ratio (Domaschke et al., 2019, pp. 1-8). 

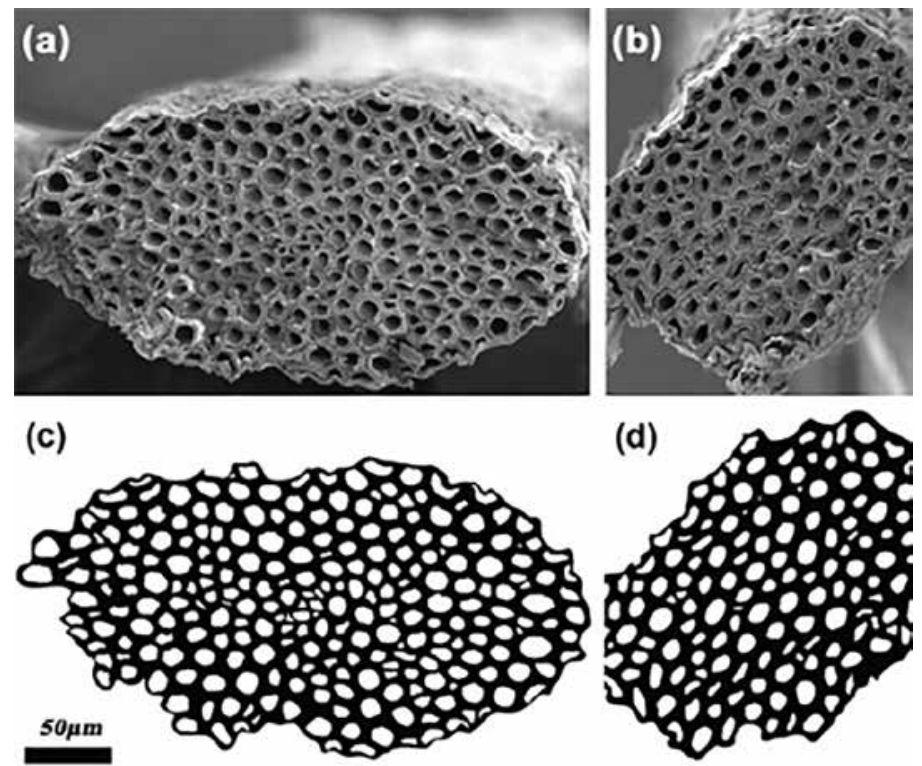

4

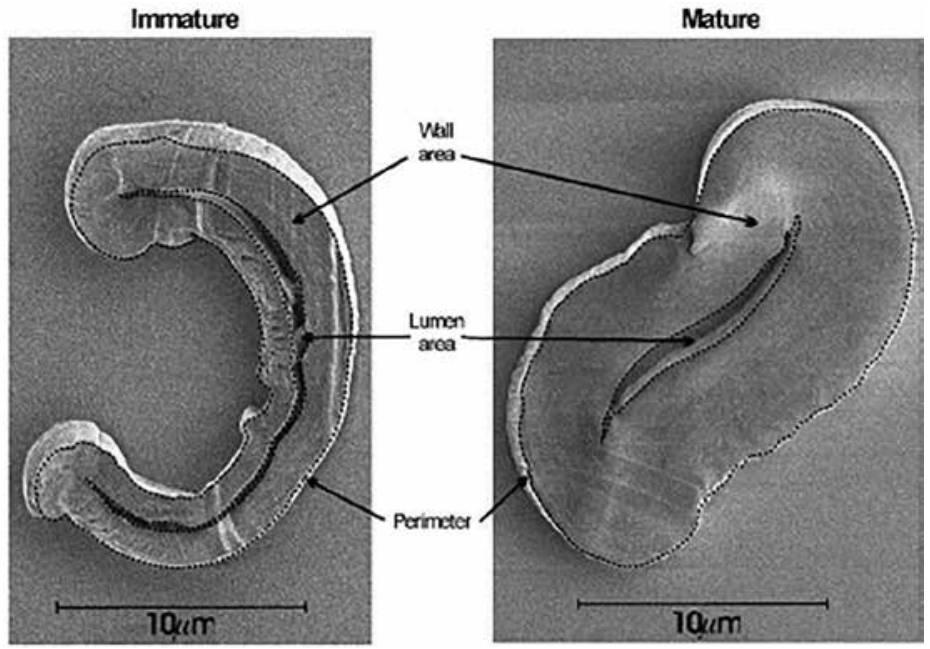

5

Figure 4. Two geometries of fragments of the same abaca fibre at different heights along the fibre stem (Liu et al., 2013, pp. 14-22). Figure 5. Two typical geometries of cotton fibre section (Gordon et al., 2017). 


\section{Conclusions}

Plant fibres have normally been adapted to the structural use (initially textile, then also in composites) instead of trying to use them as received, making full sense of their natural geometry both externally (along their length) and internally (in section). However, if the latter method is adopted, therefore leaving as much as possible the fibres as received, a number of further observations can be done about their respective shapes, their porosities, and subsequently to the way load is distributed along their length and across their section.

In practice, these specific materials, which have been adapted so far, also by the application of chemical, physical and enzymatic treatments to the false paradigm of circular section, absence of internal lacunae, and constant diameter. To make a full use of them, biomimetics would need to accept that there is a relation between the global geometry of a fibre and its variations, the cultivar from which it has been extracted and the load and the function the fibre has in the system it is a part of.

This would be of use not only for the appropriate use of plant fibres, but also to be of inspiration for the production of fibrous structures in engineering in a moment in which the digital fabrication techniques allow a higher flexibility on the local and even microscopic geometries, enabling varying the dimensional parameters also inside the same physical object, such a fibre.

\section{References}

Ahmad, F.; Choi, H. S. \& Park, M. K. (2015). A review: natural fiber composites selection in view of mechanical, light weight, and economic properties. Macromolecular materials and engineering, 300(1), 10-24.

Ahmed, S. \& Ulven, C. A. (2018). Dynamic in-situ observation on the failure mechanism of flax fiber through scanning electron microscopy. Fibers, 6(1), 17.

Bourmaud, A.; Beaugrand, J.; Shah, D. U.; Placet, V. \& Baley, C. (2018). Towards the design of high-performance plant fibre composites. Progress in Materials Science, 97, 347-408.

Bourmaud, A.; Merotte, J.; Siniscalco, D.; Le Gall, M.; Gager, V.; Le Duigou, A., ... \& Baley, C. (2019). Main criteria of sustainable natural fibre for efficient unidirectional biocomposites. Composites Part A: Applied Science and Manufacturing, 124, 105504.

Carniglia, S. C. (1986). Construction of the tortuosity factor from porosimetry. Journal of Catalysis, 102(2), 401-418.

Chen, B.; Wang, X.; Leng, W.; Mei, C. \& Zhai, S. (2019). Spectroscopic/Microscopic elucidation for chemical changes during acid pretreatment on arundo donax. Journal of Bioresources and Bioproducts, 4(3), 192-199.

De Rosa, I. M.; Kenny, J. M.; Maniruzzaman, M.; Moniruzzaman, M.; Monti, M.; Puglia, D., ... \& Sarasini, F. (2011). Effect of chemical treatments on the mechanical and thermal behaviour of okra (Abelmoschus esculentus) fibres. Composites Science and Technology, 71(2), 246-254. 
Doineau, E.; Bauer, G.; Ensenlaz, L.; Novales, B.; Sillard, C.; Bénézet, J. C., ... \& Le Moigne, N. (2020). Adsorption of xyloglucan and cellulose nanocrystals on natural fibres for the creation of hierarchically structured fibres. Carbohydrate Polymers, 248, 116713.

Domaschke, S.; Morel, A.; Fortunato, G. \& Ehret, A. E. (2019). Random auxetics from buckling fibre networks. Nature communications, 10(1), 1-8.

Gordon, S.; Rodgers, J. \& Abidi, N. (2017). Cotton fibre cross-section properties. In Cotton fibres, characteristics, uses and performance (Pp. 65-86). Nova Science publishers, Inc.

Gu, J.; Zhang, W.; Su, H.; Fan, T.; Zhu, S.; Liu, Q., \& Zhang, D. (2015). Morphology genetic materials templated from natural species. Advanced Materials, 27(3), 464-478.

Haugan, E. \& Holst, B. (2014). Flax look-alikes: Pitfalls of ancient plant fibre identification. Archaeometry, 56(6), 951-960.

Jarvis, M. C. (2018). Structure of native cellulose microfibrils, the starting point for nanocellulose manufacture. Philosophical Transactions of the Royal Society A: Mathematical, Physical and Engineering Sciences, 376(2112), 20170045.

Kalia, S.; Kaith, B. S. \& Kaur, I. (2009). Pretreatments of natural fibers and their application as reinforcing material in polymer composites-a review. Polymer Engineering \& Science, 49(7), 1253-1272.

Koch, K.; Bhushan, B. \& Barthlott, W. (2009). Multifunctional surface structures of plants: an inspiration for biomimetics. Progress in Materials science, 54(2), 137-178.

Koruk, H. \& Genc, G. (2015). Investigation of the acoustic properties of bio luffa fiber and composite materials. Materials Letters, 157, 166-168.

Legland, D. \& Beaugrand, J. (2013). Automated clustering of lignocellulosic fibres based on morphometric features and using clustering of variables. Industrial Crops and Products, 45, 253-261.

Liu, K.; Takagi, H. \& Yang, Z. (2013). Dependence of tensile properties of abaca fiber fragments and its unidirectional composites on the fragment height in the fiber stem. Composites Part A: Applied Science and Manufacturing, 45, 14-22.

Liu, M.; Thygesen, A.; Summerscales, J. \& Meyer, A. S. (2017). Targeted pre-treatment of hemp bast fibres for optimal performance in biocomposite materials: A review. Industrial crops and products, 108, 660-683.

Luz, G. M. \& Mano, J. F. (2010). Mineralized structures in nature: examples and inspirations for the design of new composite materials and biomaterials. Composites Science and Technology, 70(13), 1777-1788.

Mattrand, C.; Béakou, A. \& Charlet, K. (2014). Numerical modeling of the flax fiber morphology variability. Composites Part A: Applied Science and Manufacturing, 63, 10-20.

Melelli, A.; Durand, S.; Arnould, O.; Richely, E.; Guessasma, S.; Jamme, F., ... \& Bourmaud, A. (2021). Extensive investigation of the ultrastructure of kink-bands in flax fibres. Industrial Crops and Products, 164, 113368.

Mizuno, H.; Luengo, G. S. \& Rutland, M. W. (2013). New insight on the friction of natural fibers. Effect of sliding angle and anisotropic surface topography. Langmuir, 29(19), 5857-5862.

Mukhopadhyay, S.; Fangueiro, R.; Arpac, Y., \& Şentürk, Ü. (2008). Banana fibers-variability and fracture behaviour. Journal of Engineered Fibers and Fabrics, 3(2), 155892500800300207. 
Newman, R. H.; Le Guen, M. J.; Battley, M. A. \& Carpenter, J. E. (2010). Failure mechanisms in composites reinforced with unidirectional Phormium leaf fibre. Composites Part A: Applied Science and Manufacturing, 41(3), 353-359.

Nguong, C. W.; Lee, S. N. B. \& Sujan, D. (2013). A review on natural fibre reinforced polymer composites. International Journal of Materials and Metallurgical Engineering, 7(1), 52-59.

Patil, N. D.; Tanguy, N. R. \& Yan, N. (2016). 3-Lignin interunit linkages and model compounds. Lignin in Polymer Composites, 27-47.

Peças, P.; Carvalho, H.; Salman, H. \& Leite, M. (2018). Natural fibre composites and their applications: a review. Journal of Composites Science, 2(4), 66.

Santulli, C. (2008). A biomimetic approach to the production of sustainable structural composites using plant fibres. In Biologically inspired textiles (Pp. 95-114). Woodhead Publishing.

Santulli, C. \& Langella, C. (2016). Study and development of concepts of auxetic structures in bio-inspired design. International Journal of Sustainable Design, 3(1), 20-37.

Sarasini, F. \& Fiore, V. (2018). A systematic literature review on less common natural fibres and their biocomposites. Journal of cleaner production, 195, 240-267.

Sfiligoj Smole, M.; Hribernik, S.; Stana Kleinschek, K. \& Kreže, T. (2013). Plant fibres for textile and technical applications. Advances in agrophysical research, 369-398.

Soltani, P.; Taban, E.; Faridan, M.; Samaei, S. E. \& Amininasab, S. (2020). Experimental and computational investigation of sound absorption performance of sustainable porous material: Yucca Gloriosa fiber. Applied Acoustics, 157, 106999.

Šturcová, A.; His, I.; Apperley, D. C.; Sugiyama, J. \& Jarvis, M. C. (2004). Structural details of crystalline cellulose from higher plants. Biomacromolecules, 5(4), 1333-1339.

Summerscales, J.; Hall, W. \& Virk, A. S. (2011). A fibre diameter distribution factor (FDDF) for natural fibre composites. Journal of materials science, 46(17), 5876-5880.

Verma, P.; Smith, C. L.; Griffin, A. C. \& Shofner, M. L. (2020). Wool nonwovens as candidates for commodity auxetic materials. Engineering Research Express, 2(4), 045034.

Ververis, C.; Georghiou, K.; Christodoulakis, N.; Santas, P. \& Santas, R. (2004). Fiber dimensions, lignin and cellulose content of various plant materials and their suitability for paper production. Industrial crops and products, 19(3), 245-254.

Walton, W. H. (1948). Feret's statistical diameter as a measure of particle size. Nature, 162(4113), 329-330.

Wang, D.; Wang, Z.; Zheng, X. \& Tian, M. (2020). Activated carbon fiber derived from the seed hair fibers of Metaplexis japonica: novel efficient adsorbent for methylene blue. Industrial Crops and Products, 148, 112319.

Wegst, U. G. K. \& Ashby, M. F. (2004). The mechanical efficiency of natural materials. Philosophical Magazine, 84(21), 2167-2186.

Yue, H.; Rubalcaba, J. C.; Cui, Y.; Fernández-Blázquez, J. P.; Yang, C. \& Shuttleworth, P. S. (2019). Determination of cross-sectional area of natural plant fibres and fibre failure analysis by in situ SEM observation during microtensile tests. Cellulose, 26(8), 4693-4706.

Zeng, X.; Mooney, S. J. \& Sturrock, C. J. (2015). Assessing the effect of fibre extraction processes on the strength of flax fibre reinforcement. Composites Part A: Applied Science and Manufacturing, 70, Pp. 1-7. 
Resumen: Las fibras vegetales, que se basan en estructuras ligno-celulósicas, están dispuestas como compuestos biomiméticos, en el sentido de que incluyen una relación compleja entre una matriz más blanda y un refuerzo más duro a través de una interfaz, con uso continuo de porosidades y arreglos celulares. Sin embargo, las fibras se pueden extraer de diferentes partes de la planta según la especie, en la práctica del tallo, la corteza, el fruto, la hoja o incluso la semilla. Existe una relación entre la región de las fibras y su estructura, que este trabajo pretende discutir, presentando una gran variedad de fibras, geometrías y colocaciones en la propia planta.

Palabras clave: Fibras vegetales - Lúmenes - Bandas de torsión - Soporte de carga - Diseño natural

Resumo: As fibras vegetais, que se baseiam em estruturas lignocelulósicas, apresentam-se como compósitos biomiméticos, no sentido de que apresentam uma relação complexa entre uma matriz mais macia e um reforço mais duro por meio de uma interface, com uso contínuo de porosidades e arranjos celulares. Porém, as fibras podem ser extraídas de diferentes partes da planta de acordo com a espécie, na prática do caule, da casca, do fruto, da folha ou mesmo da semente. Existe uma relação entre a região das fibras e sua estrutura, que este trabalho pretende discutir, apresentando uma grande variedade de fibras, geometrias e colocações na própria planta.

Palavras chave: Fibras vegetais - Lúmen - Faixas dobradas - Suporte de carga - Desenho natural 